\title{
Ni-YSZ solid oxide fuel cell anode behavior upon redox cycling based on electrical characterization
}

\section{Klemensø, Trine; Mogensen, Mogens Bjerg}

\section{Published in:}

Proceedings of Materials Science and Technology 2006 Meeting

Publication date:

2006

Link back to DTU Orbit

Citation (APA):

Klemensø, T., \& Mogensen, M. B. (2006). Ni-YSZ solid oxide fuel cell anode behavior upon redox cycling based on electrical characterization. In Proceedings of Materials Science and Technology 2006 Meeting

\section{General rights}

Copyright and moral rights for the publications made accessible in the public portal are retained by the authors and/or other copyright owners and it is a condition of accessing publications that users recognise and abide by the legal requirements associated with these rights.

- Users may download and print one copy of any publication from the public portal for the purpose of private study or research.

- You may not further distribute the material or use it for any profit-making activity or commercial gain

- You may freely distribute the URL identifying the publication in the public portal

If you believe that this document breaches copyright please contact us providing details, and we will remove access to the work immediately and investigate your claim 


\title{
Ni-YSZ solid oxide fuel cell anode behavior upon redox cycling based on electrical
}

\section{characterization $^{\mathrm{a}}$}

\author{
Trine Klemensø $\emptyset^{1,2,3, \mathrm{~b}}$, Mogens Mogensen ${ }^{1}$ \\ ${ }^{1}$ Risø National Laboratory, Fuel Cells and Solid State Chemistry Department, 4000 Roskilde, \\ Denmark \\ 2 Technical University of Denmark, Department of Chemistry, building 207, 2800 Kgs. Lyngby, \\ Denmark \\ ${ }^{3}$ Topsoe Fuel Cell, 2800 Kgs. Lyngby, Denmark
}

\begin{abstract}
Ni-YSZ cermets are a prevalent material used for solid oxide fuel cells. However, the cermet degrades upon redox cycling. The degradation is related to microstructural changes, but knowledge of the mechanisms has been limited. DC conductivity measurements were performed on cermets and cermets, where the Ni component was removed, before, during and after redox cycling the cermet. The cermet conductivity degraded over time due to sintering of the nickel phase. Following oxidizing events, the conductivity of the cermets improved, whereas the conductivity of the YSZ phase decreased. A model of the redox degradation mechanism was established based on the measurements.
\end{abstract}

\footnotetext{
a To be presented at the Materials Science \& Technology 2006 Meeting, Cincinnati, OH, October 15-19, 2006 (Fuel Cells and Energy Storage Systems: Materials, Processing, Manufacturing and Power Management Technologies, Paper No. XXX).

b E-mail: trine.klemensoe@risoe.dk
} 


\section{Introduction}

Redox stability of the electrochemically active anode and the structurally supporting part of the cell, the anode-support, is considered critical for small- to medium-scale solid oxide fuel cell (SOFC) systems [1]. In the prevalent SOFC design, the anode and the support are nickel-YSZ (yttria stabilized zirconia) cermets. Redox cycling of the cermets results in degradation of the cell performance [1, 2]. The degradation is related to microstructural changes, causing bulk expansion of the cermet structure, which then results in the formation of cracks in the electrolyte. However, further knowledge of the degradation mechanisms is limited [1-4].

DC (direct current) conductivity measurements appear as a useful tool in reflecting microstructural changes in the cermet structure. The technique has been used to study nickel sintering [5, 6], the nickel reduction process [7], and the effect of oxidizing events [8, 9].

In this work, the changes in the cermet microstructure upon redox cycling were characterized using DC conductivity measurements. Measurements were done on cermets with different ceramic compositions and on cermet structures, where the Ni component was removed. The conductivity was measured continuously during redox cycling, or before and after the cermet had been redox cycled. A model of the redox degradation mechanism is proposed based on the measurements.

\section{Experimental Procedure}

\section{$\underline{\text { Sample preparation }}$}


Cermet samples were prepared from $\mathrm{NiO}$ powder (Alfa Aesar), alumina powder (Sasol), and 3 mol\% or 8 mol\% yttria stabilized zirconia powder (3YSZ or 8YSZ, respectively TZ-3YB or TZ8Y from Tosoh Co.). Two compositions with similar NiO contents, and either 3YSZ or 8YSZ were prepared. The two compositions were denoted $8 \mathrm{Y}$ and $3 \mathrm{Y}$, and the solid material contents were respectively $56.8 \mathrm{wt} \% \mathrm{NiO}, 43.2 \mathrm{wt} \% 8 \mathrm{YSZ}$ for $8 \mathrm{Y}$, and $55.7 \mathrm{wt} \% \mathrm{NiO}, 43.7 \mathrm{wt} \% 3 \mathrm{YSZ}$, $0.6 \mathrm{wt} \% \mathrm{Al}_{2} \mathrm{O}_{3}$ for $3 \mathrm{Y}$.

The powders were processed into slurries that were tape cast into thin foils. A part of the green foils was heat treated into powder, and the powder was pressed (uniaxial followed by isostatic pressing at $80 \mathrm{MPa}$ ) into bar shaped samples. The green foils and the bars were sintered at $1300^{\circ} \mathrm{C}$. After sintering, the bars were mechanically cut down into lengths of $20 \mathrm{~mm}$, and the foils were cut by laser into strips of $9 \mathrm{~mm}$ width and $50 \mathrm{~mm}$ length.

A portion of the sintered samples were reduced at $1000^{\circ} \mathrm{C}$ with 9 vol\% $\mathrm{H}_{2}$ in $\mathrm{N}_{2}$ for 96 hours. A portion of these were subsequently re-oxidized (at $1000^{\circ} \mathrm{C}$ in air for 1 hour), and then re-reduced again (at $1000^{\circ} \mathrm{C}$ in 9 vol\% $\mathrm{H}_{2}$ in $\mathrm{N}_{2}$ for 96 hours). Following this, the metallic nickel was removed by acid treatment. A 10 molar hydrochloric acid (10 $\mathrm{M} \mathrm{HCl})$ in combination with periods of heating was applied. The samples were exposed to the acid until constant weight was attained. The exposure time lasted from 138-342 hours. 


\begin{tabular}{|c|c|c|c|c|c|c|}
\hline \multicolumn{7}{|c|}{ Table I. List of the samples tested with DC conductivity. The sample name indicates tvpe of } \\
\hline \multicolumn{7}{|c|}{ for cermets, and pre-treatment of the cermet before nickel removal for the porous YSZ. } \\
\hline \multicolumn{7}{|c|}{ Identical tests are separated by a serial letter added to the last part of the sample name. The } \\
\hline temperatu & e range $\left(T_{\text {meas }}\right)$ & which m & asurem & its were carried is $s$ & $n$ in the 1 & column. \\
\hline Sample type & Sample name & Ceramic & Shape & Pre-treatment & $\mathrm{T}_{\text {red }}\left[{ }^{\circ} \mathrm{C}\right]$ & $\mathrm{T}_{\text {meas }}\left[{ }^{\circ} \mathrm{C}\right]$ \\
\hline \multirow[t]{6}{*}{ Cermet } & $8 Y-b a r-1000$ & 8YSZ & Bar & - & 1000 & 1000 \\
\hline & 8Y-strip-1000 & $8 Y S Z$ & Strip & - & 1000 & 1000 \\
\hline & 3Y-bar-1000-a & 3YSZ & Bar & - & 1000 & 1000 \\
\hline & 3Y-bar-1000-b & $3 Y S Z$ & Bar & - & 1000 & 1000 \\
\hline & 3Y-bar-1000-c & $3 Y S Z$ & Bar & - & 1000 & 1000 \\
\hline & 3Y-strip-1000 & 3YSZ & Strip & - & 1000 & 1000 \\
\hline \multirow[t]{4}{*}{ Porous YSZ } & P-8Y-bar-red & $8 Y S Z$ & Bar & Reduction + acid & - & $500-1000$ \\
\hline & P-8Y-bar-redox & 8YSZ & Bar & Redox cycle + acid & - & $500-1000$ \\
\hline & P-3Y-bar-red & 3YSZ & Bar & Reduction + acid & - & $500-1000$ \\
\hline & P-3Y-bar-redox & 3YSZ & Bar & Redox cycle + acid & - & $500-1000$ \\
\hline
\end{tabular}

A list of the samples tested with DC conductivity is shown in Table I. The two types of samples (cermet and porous YSZ without nickel) are differentiated by a prefixed "P" in the sample name. The subsequent parts of the sample names refer to the composition of the ceramic component, and the sample shape. The last part of the sample name refers to the temperature of reduction 
( $\left.\mathrm{T}_{\text {red }}\right)$ for the cermets, and to the pre-treatment of the cermet before nickel removal for the porous YSZ. Tests of identical samples performed under identical conditions are separated by a serial letter added to the last part of the sample name. The temperature range ( $\left.T_{\text {meas }}\right)$ at which measurements were carried out is included in Table I.

\section{Measurements}

A 4-electrode set-up was applied for the DC conductivity measurements. The set-up is shown in Figure 1. Electrodes of platinum (Pt) wire were mounted onto the strip and bar shaped samples. For measurement on bars, the current electrode wires were wrapped around the sample ends (cf. Figure 1 left). The wires were guided by mechanically cut grooves at the edges of the bar. To ensure contact, Pt paste was applied. Potential probes fixed in the DC set-up were used for the bars. The probes were distanced by ca. $7 \mathrm{~mm}$ in the set-up, and were contacted to the center of the bar by a spring load (cf. Figure 1).

For measurement on strips, both current and potential probes were applied to the sample (cf. Figure 1 right). For mechanical handling, the samples were placed on top of a ca. $2 \mathrm{~mm}$ thick ceramic plate. The Pt wires were wrapped around the joined sample and support plate, guided by grooves cut into the support plate. Potential probes were placed symmetrically around the center of the sample spaced $12 \mathrm{~mm}$ apart. Current probes were attached at the ends. Pt paste was also applied to ensure contact. The paste was sintered at $1100^{\circ} \mathrm{C}$ for 1 hour before measurements. 

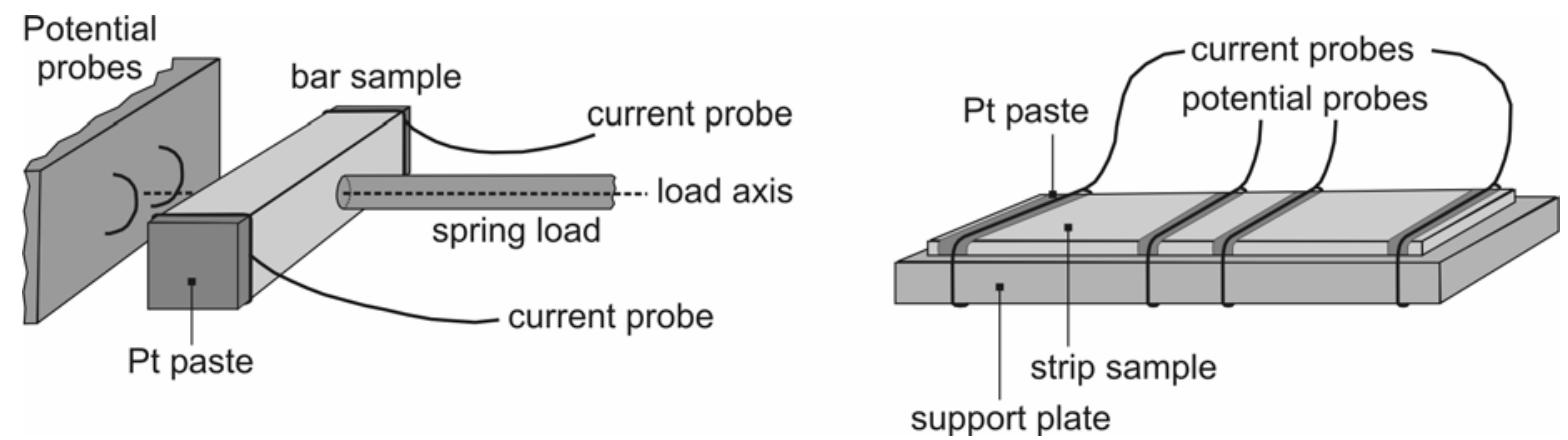

Figure 1: The experimental set-up for DC measurements on bar (left) and strip (right) shaped samples.

The samples were heated to the desired temperature $\left(1000^{\circ} \mathrm{C}\right)$ in air, with a gas flow rate of 100 $\mathrm{ml} / \mathrm{min}$ (adjusted at $25^{\circ} \mathrm{C}$ ). The cermets were subsequently reduced in a dry $4.5 \mathrm{vol} \% \mathrm{H}_{2}-\mathrm{N}_{2}$ mixture with the same total gas flow. Redox cycling was carried out by changing the gas flow to air for ca. 24 hours. $\mathrm{N}_{2}$ was used as flushing gas for ca. 15 min in-between gas-shifts.

The $\mathrm{pO}_{2}$ and the resistance were logged with 1-15 minutes interval. The resistance was measured using a Keithley 580 micro-ohmmeter. A current pulse defined by the hardware was enforced in both directions, and the potential between the probes measured. The resolution of the instrument in the measurement range of $200 \mathrm{~m} \Omega$ was $10 \mu \Omega$. For reliability reasons, a measurement was rejected if the resistance for opposite current directions differed by more than $5 \%$. Otherwise, the average of the two resistances was used to calculate the conductivity $(\sigma)$.

The microstructure of the samples was investigated with a scanning electron microscopy (SEM). A Fei Quanta 600 equipped with an $\mathrm{EDAX}^{\circledR}$ thin window detector and EDAX Genesis software was used. 
Sample porosity was quantified by mercury porosimetry, or by weighing and geometric gauging. An Autopore IV 9500 V1.05 instrument from Micromeritics Instrument Corporation was used as mercury porosimeter. The samples were weighed with a Mettler AE 163, and the dimensions measured with a Vernier gauge, and a Mitutoyo 7002 dial thickness gauge.

\section{Results}

\section{Cermet conductivity}

An example of a conductivity profile and the simultaneously obtained profile of the oxygen partial pressure $\left(\mathrm{pO}_{2}\right)$ is shown in Figure 2. The profiles were acquired by continuous measurements during successive periods of reducing and oxidizing conditions as reflected by the course of the $\mathrm{pO}_{2}$ curve. The electrical behavior was characterized by the parameters: $\sigma_{\mathrm{r}, \mathrm{i}}, \mathrm{t}_{\mathrm{r}, \mathrm{i}}$, $\Delta \sigma_{24, \mathrm{i}}, \Delta \sigma_{96, \mathrm{i}}$, and $\Delta \sigma_{\text {redox,i }}$, where i refers to the order of the reducing period. The parameters are illustrated in Figure 2 for the first reducing period $(\mathrm{i}=1)$. The time was set to zero $(\mathrm{t}=0 \mathrm{~h})$ when the reducing gas flow was started. The reducing conditions were immediately followed by an increase in conductivity as the reduction progressed into the sample. When maximum or constant conductivity was obtained, the sample was assumed completely reduced. The time for complete reduction is denoted $t_{r, 1}$, and the conductivity at this point is $\sigma_{r, 1}$ (cf. Figure 2). 


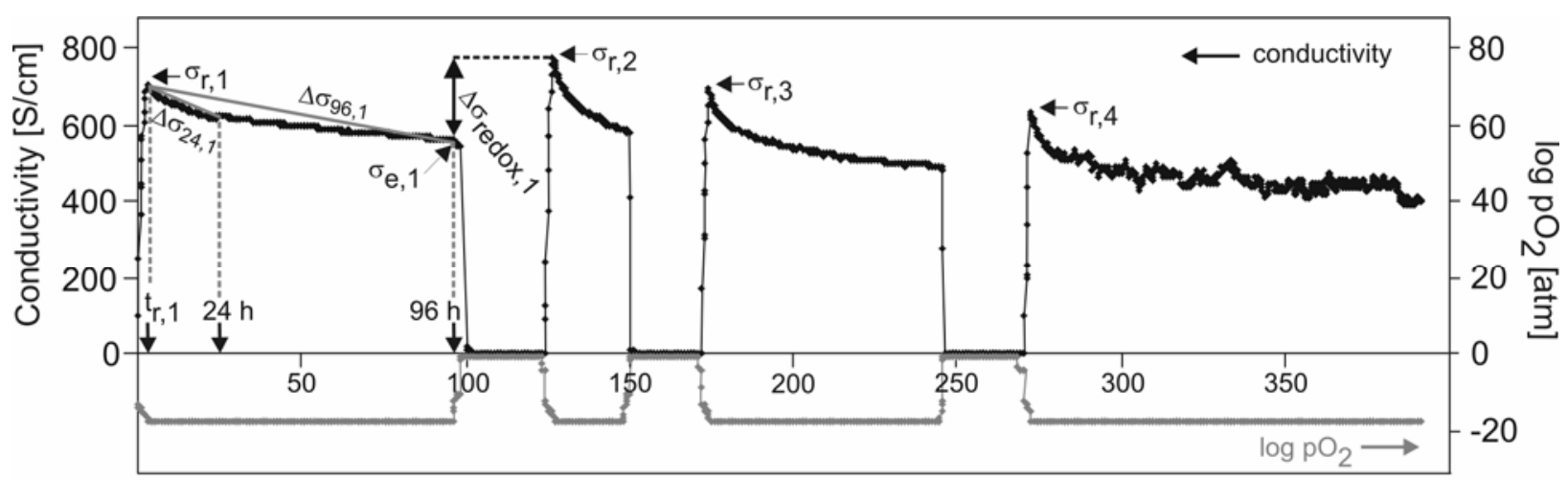

Time $[\mathrm{h}]$

Figure 2: Characteristic conductivity (black) and $\mathrm{pO}_{2}$ (gray) profiles for a cermet sample. The parameters used to characterize the electrical behavior are illustrated for the first reducing period (indicated with "1" in the subscripts). $\sigma_{\mathrm{r}, 1}$ and $\mathrm{t}_{\mathrm{r}, 1}$ is respectively the time and conductivity at the initial complete reduction. $\Delta \sigma_{24,1}$ and $\Delta \sigma_{96,1}$ describes the degradation by the slope of the straight line between the initial complete reduction and the measurement points after 24 and 96 hours of reducing conditions. $\sigma_{\mathrm{e}, 1}$ is the conductivity at the end of first reducing period just before flushing with $\mathrm{N}_{2}$, and $\Delta \sigma_{\text {redox,1 }}$ is the relative change in conductivity between before and after the first oxidizing event. For the following reducing periods corresponding parameters were defined.

The conductivity generally decreased during reducing conditions. The ageing was rapid in the beginning, and diminished with time. Full relaxation was not achieved during the measured periods (cf. Figure 2). To quantify the degradation, the slope of the straight line between the initial fully reduced state $\left(t_{r, 1}, \sigma_{r, 1}\right)$ and the measured points after respectively $24\left(t_{24,1}, \sigma_{24,1}\right)$ and $96\left(\mathrm{t}_{96,1}, \sigma_{96,1}\right)$ hours of test was used. The slopes were denoted $\Delta \sigma_{24,1}$ and $\Delta \sigma_{96,1}$, and calculated as illustrated in Equation 1 for $\Delta \sigma_{24,1}$. The unit is $S \cdot \mathrm{cm}^{-1} \cdot \mathrm{h}^{-1}$. 


$$
\Delta \sigma_{24,1}=\frac{\sigma_{24,1}-\sigma_{r, 1}}{t_{24,1}-t_{r, 1}}
$$

The conductivity was observed to differ before and after a re-oxidizing event (cf. Figure 2). The relative change was denoted $\Delta \sigma_{\text {redox,1, }}$ and calculated as shown in Equation 2, where $\sigma_{\mathrm{e}, 1}$ is the conductivity at the end of first reducing period before flushing with $\mathrm{N}_{2}$. A minor decrease in the conductivity was associated with flushing. During the first redox cycles, $\Delta \sigma_{\text {redox,i }}$ was generally positive as seen in Figure 2. However, the positive effect decreased, and in some cases became negative, with increasing number of redox cycles.

$$
\Delta \sigma_{\text {redox }, 1}=\frac{\sigma_{\mathrm{r}, 2}-\sigma_{\mathrm{e}, 1}}{\sigma_{\mathrm{e}, 1}}
$$

The uncertainty on the parameters was estimated from a reproducibility study, where three nominally identical samples of the type 3Y-bar-1000 were tested. The uncertainty on the time for complete reduction $\left(\mathrm{t}_{\mathrm{r}, \mathrm{i}}\right)$ was estimated to $0.25 \mathrm{~h}$. The uncertainty on the conductivity was estimated to be $5 \%$, and the uncertainty on the calculated degradation rate and oxidation effect was estimated to be $1 \mathrm{~S} \cdot \mathrm{cm}^{-1} \cdot \mathrm{h}^{-1}$ and $10 \%$, respectively. 


\section{$\underline{\text { Porosity }}$}

The electrical properties were observed to depend on the sample porosity. Figure 3 shows the electrical parameters for the first reducing period as a function of the as-sintered porosity for samples reduced at $1000^{\circ} \mathrm{C}$.

The conductivity after complete reduction was seen to decrease with porosity (cf. Figure 3, upper graph). The relationship has been described in the literature with a power law $[10,11]$. The trend for the theoretical relationship is included in the diagram and appears to represent the measured data well.

The degradation pattern for the two compositions appeared similar (cf. Figure 3, middle graph). For porosity below $8.5 \%$ increased porosity was associated with increased degradation. However, above $8.5 \%$ porosity the degradation appeared unaffected by further increases in porosity.

The relationship between porosity and the effect of the first re-oxidation differed between the two compositions (cf. Figure 3, lower graph). For the 3Y composition, higher porosity seemed to generate better conductivity upon the first oxidation. For the $8 \mathrm{Y}$ composition, higher porosity was observed to have the opposite effect.

\section{Composition of the ceramic component}

An effect of the yttria content in the ceramic component on the electrical parameters was indicated. The samples of the composition 3Y displayed slightly faster degradation rates, particularly on the 24 hours scale (cf. Figure 3, middle graph). Also, the effect of the first oxidation differed between the two compositions. For 3Y, the first redox cycle was associated 
with increased conductivity. For $8 Y$, the positive effect was lower or decreased conductivity was observed (cf. Figure 3, lower graph).
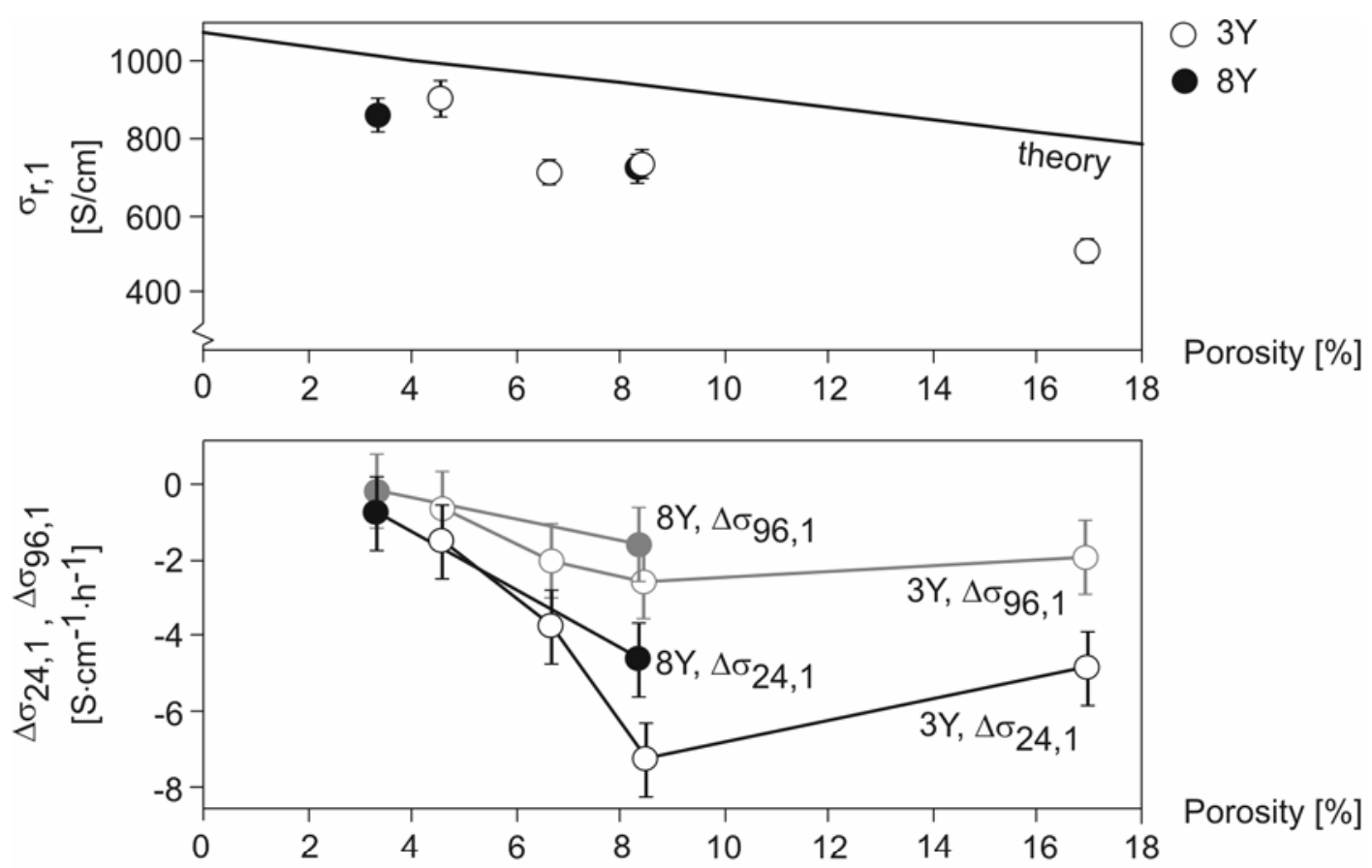

Porosity [\%]

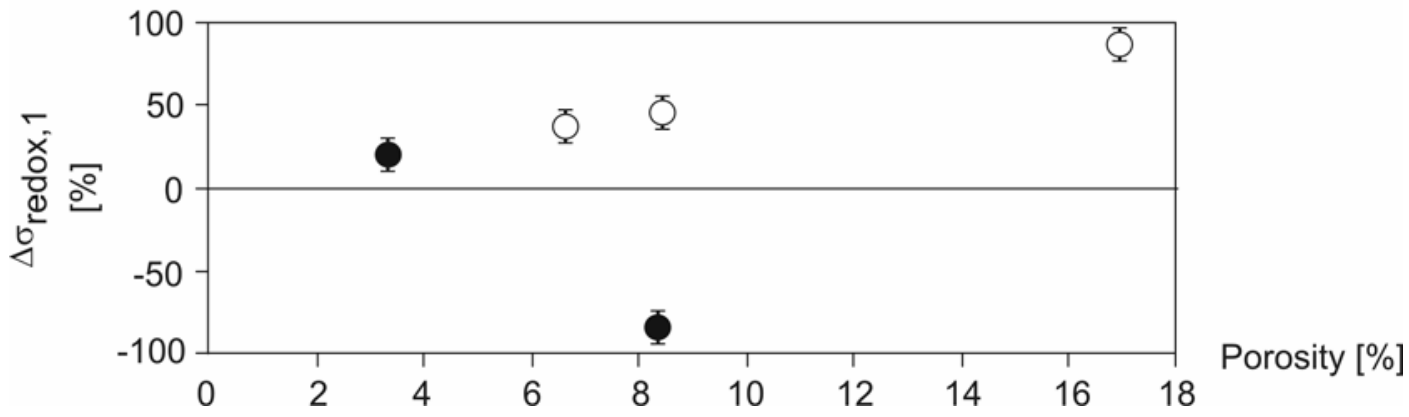

Figure 3: Electrical properties for the first reducing period as a function of the as-sintered porosity for samples reduced at $1000^{\circ} \mathrm{C}$. Samples of composition $3 \mathrm{Y}$ and $8 \mathrm{Y}$ are shown with open and closed symbols, respectively. The error bars indicate the uncertainty on the electrical measurements. The uncertainty on the porosity corresponds to the size of the measurement points. A theoretical trend for the relationship between porosity and conductivity is included in 
the $\sigma_{\mathrm{r}, 1}$ diagram and the curve denoted "theory". Degradation rates after 96 hours are shown in gray.

\section{Measurements on porous YSZ}

The porous YSZ structures were produced by dissolving the nickel phase with acid. Complete removal of the nickel upon the acid treatment was indicated by no further weight change, SEM, and EDS (energy dispersive spectroscopy) investigations. However, the samples preserved a grayish color after the acid treatment. The color vanished after heat treatment at $1100^{\circ} \mathrm{C}$ in air. This indicated that some of the Ni remained in the structure after the exposure to acid. This is likely to be nickel particles that are enclosed within the YSZ matrix preventing access of the acid. Upon heat treatment the NiO dissolved into YSZ causing the gray color to disappear. The amount of residual $\mathrm{Ni}$ is believed to be minor as the solubility of $\mathrm{NiO}$ in $\mathrm{YSZ}$ is below $2 \mathrm{~m} / \mathrm{o}$ at $1600^{\circ} \mathrm{C}$ and increasing with temperature [12].

The treatment with acid was observed to affect the ceramic phase as well. ICP-OES (inductively coupled plasma optical emission spectroscopy) analyses of the acids used showed significant yttrium contents. At least $37 \mathrm{ppm}$ of the yttria present in the samples was estimated to be dissolved from the structures simultaneously with the dissolution of nickel.

The porosity of the acid treated samples was measured with mercury porosimetry. The pore size distributions and total porosity $\left(\varepsilon_{\mathrm{Hg}}\right)$ are shown in Figure 4 . The total porosity of the samples representing the structures in the reduced state (P-8Y-bar-red and P-3Y-bar-red) was similar, but the pore size distribution appeared slightly coarser for the 3Y sample. For both compositions, the 
total porosity was higher for the corresponding redox cycled structures (P-8Y-bar-redox and P3Y-bar-redox), and the pore size distribution appeared to be coarser.

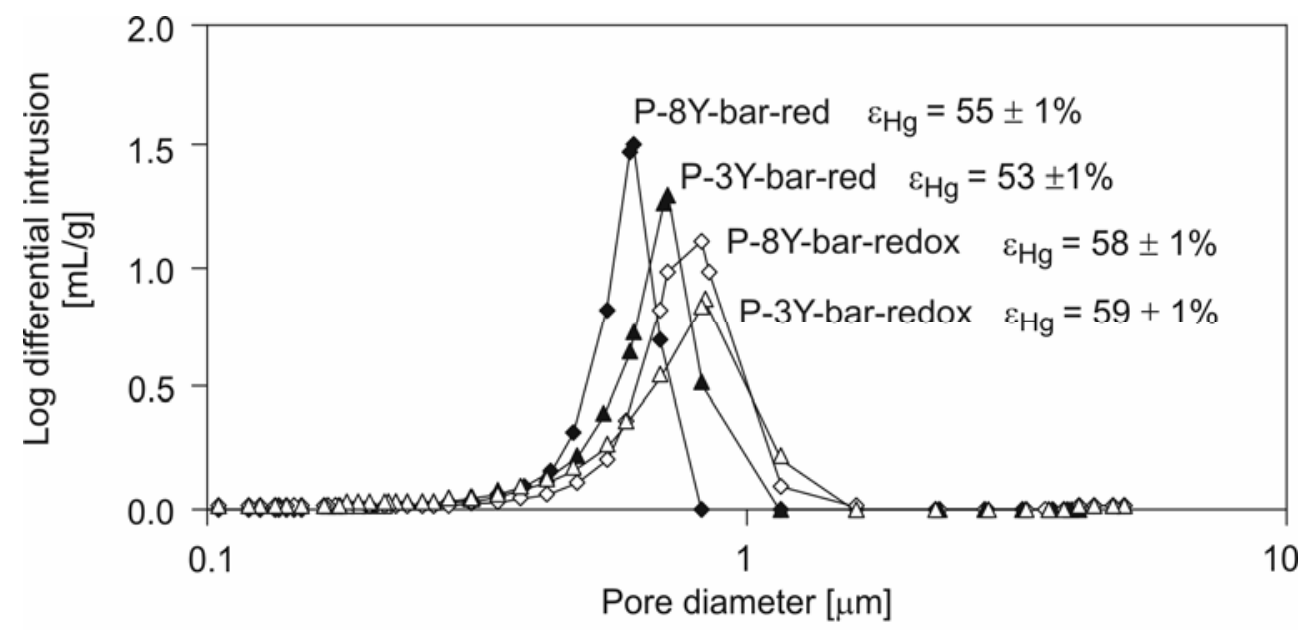

Figure 4: Pore size distribution and porosity $\left(\varepsilon_{\mathrm{Hg}}\right)$ of the porous YSZ samples after acid treatment as measured by mercury porosimetry. Samples that were reduced before acid treatment are shown with solid symbols, and samples that were redox cycled once before acid treatment are shown with open symbols.

The conductivity of the porous bar shaped samples was tested with the set-up illustrated in Figure 1. Infiltration of the applied Pt paste into the porous samples was not observed. The conductivity of the samples was measured in the temperature range $500-1000^{\circ} \mathrm{C}$ with $100^{\circ} \mathrm{C}$ intervals. Each temperature was held for 5-10 hours, and the average conductivity of the period determined.

Arrhenius plots for the samples are shown in Figure 5. The curve for a dense 8YSZ is included in the figure for comparison. The conductivity of the porous samples was approximately an order of 
magnitude below the dense sample. However, the trend of the curves was similar with an activation energy $\left(E_{a}\right)$ of $84 \mathrm{~kJ} / \mathrm{mol}$.

When comparing the two compositions, the $3 \mathrm{Y}$ samples displayed lower conductivity than $8 \mathrm{Y}$. This is in accordance with the knowledge regarding conductivity of zirconia [13]. When comparing the samples representing the YSZ network in the reduced state and the redox cycled YSZ network (i.e. comparison of P-8Y-bar-red with P-8Y-bar-redox, and P-3Y-bar-red with P3Y-bar-redox), the conductivity was lower for the network where the cermet had been subjected to a redox cycle. Further, the relative decrease was more pronounced for the samples of composition $8 Y$ (са. 38\%), compared to the $3 Y$ composition (ca. 25\%).

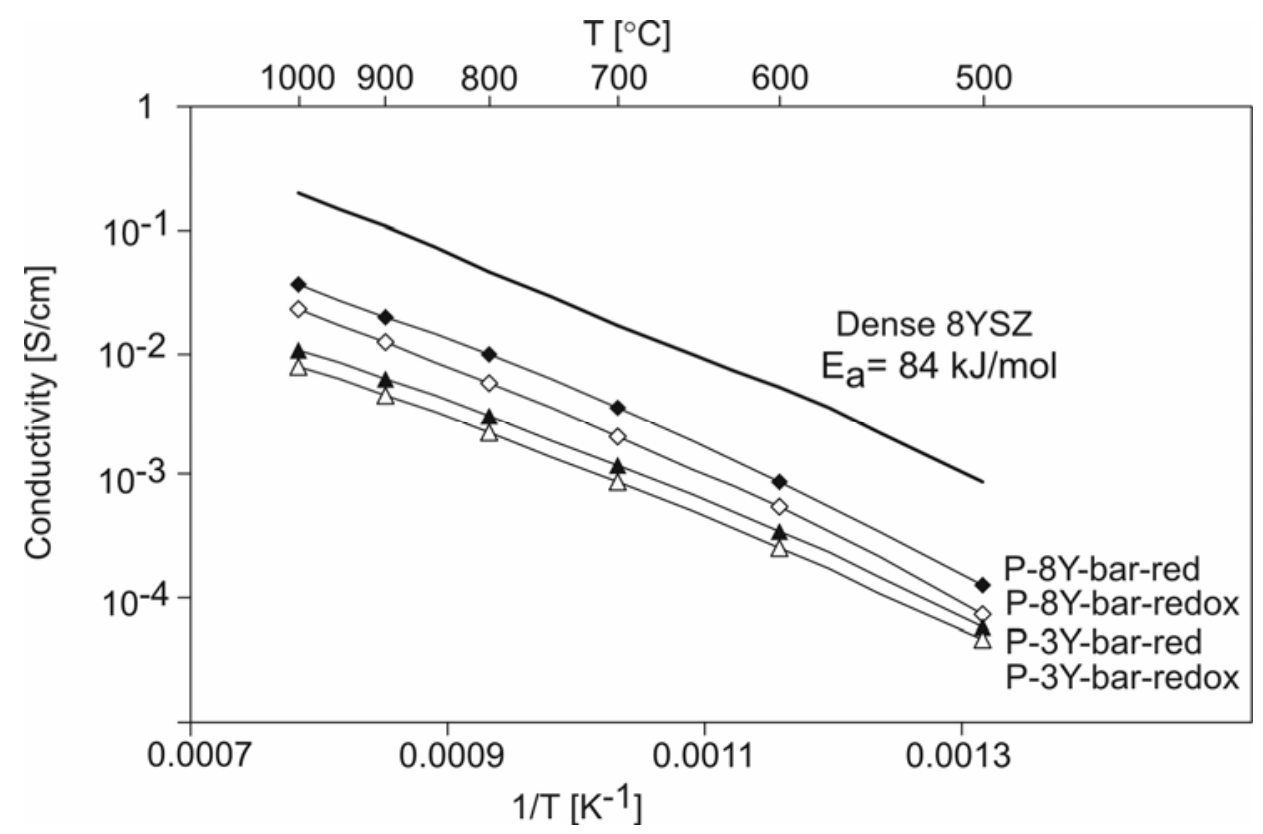

Figure 5: Arrhenius plots for dense YSZ, and the porous acid treated samples. The activation energy $\left(E_{a}\right)$ based on the slope of the linear curve is included. Samples that were reduced before acid treatment are shown with solid symbols, and samples that were redox cycled once before 
acid treatment are shown with open symbols.

\section{Discussion}

Characterization of the microstructural changes of Ni-YSZ cermets is known to be difficult [6, 14]. For instance, direct observation of nickel coarsening requires long-term experiments (typically > 1000 hours) and is laborious to evaluate quantitatively [6, 15-17]. However, electrical DC measurements on the bulk structure appeared as a viable and sensitive technique for detecting variations in microstructures, as well as reorganizations of the Ni phase over short time ranges $(<24$ hours $)$.

Degradation of the cermet conductivity generally followed immediately upon complete reduction. The decrease in the electronic conductivity is believed to reflect Ni coarsening and agglomeration. Grain growth and particle coalescence will imply loss of nickel particle contacts. When the number of contact points decreases, so does the number of electrical pathways. The decrease in percolation degree causes the observed decrease in bulk conductivity. Similar observations have been reported in the literature $[5-7,16,18,19]$. The driving force for the nickel sintering has been ascribed to the poor wettability between Ni and YSZ [15]. Higher yttria contents reduced the degradation significantly. In the literature, the composition of the ceramic component has also been pointed out as an important parameter [16, 18-21].

Upon a redox cycle (i.e. an event of oxidation and subsequent re-reduction), the cermet conductivity generally increased. The opposite was observed for the conductivity of the YSZ network. The changes show that the redox cycle promotes improved percolation of the $\mathrm{Ni}$ network, and weakens the YSZ network. 
From in-situ ESEM (environmental scanning electron microscopy) studies it has been observed that re-oxidation of the $\mathrm{Ni}$ grains involves reorganization of the $\mathrm{Ni} / \mathrm{NiO}$ phase [22]. If the $\mathrm{Ni}$ oxidation proceeded fast (i.e. at temperatures around $800^{\circ} \mathrm{C}$ ), the nickel particles were seen to divide into several particles, which then grew into the surrounding voids. The reorganization is believed to account for the improved percolating Ni network.

Redox cycling was observed to be associated with increased porosity. Further, previous SEM studies have shown that mechanical damage is inflicted on the YSZ network upon the reoxidation [4]. The mechanical damage is believed to be reflected in the weakened YSZ percolation. In accordance with previous observations, less damage, or less percolation loss, was seen for the mechanically stronger $3 \mathrm{Y}$ cermet.

Upon succeeding re-oxidizing events, the improvement in cermet conductivity diminished. This is believed to reflect that as the structure becomes increasingly damaged, the formation of a wellpercolating Ni-network becomes increasingly difficult.

\section{The redox mechanism}

The descriptions of the redox mechanism were previously limited to the observation of a bulk expansion of the cermet structure, inflicting mechanical damage onto the cell, and degraded performance. The bulk expansion was generally, without details, explained by the volume difference between $\mathrm{Ni}$ and $\mathrm{NiO}[1-4,23]$.

Based on the observations in the present work, a model of the redox mechanism on the microstructural level is proposed. The model is illustrated in the cartoon in Figure 6. The darker gray particles represent respectively $\mathrm{NiO}$ and $\mathrm{Ni}$, and the lighter gray matrix is the YSZ component of the cermet. Pores and fractures are shown in white. The electrolyte and current 
collector placed adjacent to the nickel-YSZ cermet is also shown. The microstructural evolution in the steps shown in Figure 6 is described below.

(a) The as-sintered structure consists of pores, and percolating networks of NiO and YSZ.

(b) Upon reduction the nickel phase reorganizes due to the volume reduction of the phase and the changed wetting properties. The nickel particles become rounded, and particle sintering occurs.

(c) Upon re-oxidation the microstructure does not revert to the as-sintered state. Reversion is prevented by the nickel redistribution that occurred in the reduced state and the oxide growth.

The oxide growth is guided by the oxidation kinetics, and the local pore morphology. When the oxidation kinetics is fast, the $\mathrm{Ni} / \mathrm{NiO}$ particles divide into 2-4 particles that grow into the surrounding voids, as illustrated.

Where the growth of the particles cannot be accommodated within the structure, stresses are generated in the YSZ matrix. At weak points, or where the stresses are higher, the YSZ network fractures. This permits bulk expansion of the cermet which generates cracks in the electrolyte.

(d) When the structure is re-reduced, an improved percolating nickel network is formed compared to the first reduced state. This is facilitated by the partial disintegrated YSZ network, and the $\mathrm{NiO}$ redistribution that occurred during the oxide growth.

(e) The steps described in (c-d) are repeated upon succeeding redox cycling. Re-oxidations are associated with fractures in the YSZ matrix, bulk expansion, and cracks in the electrolyte as long as $\mathrm{Ni} / \mathrm{NiO}$ redistribution occurs. 
(f) Reductions are associated with improved nickel percolation as long as the structure is not too fragmented. At a critical porosity the ability to form a well percolating nickel network is lost. 
(a) As-sintered state

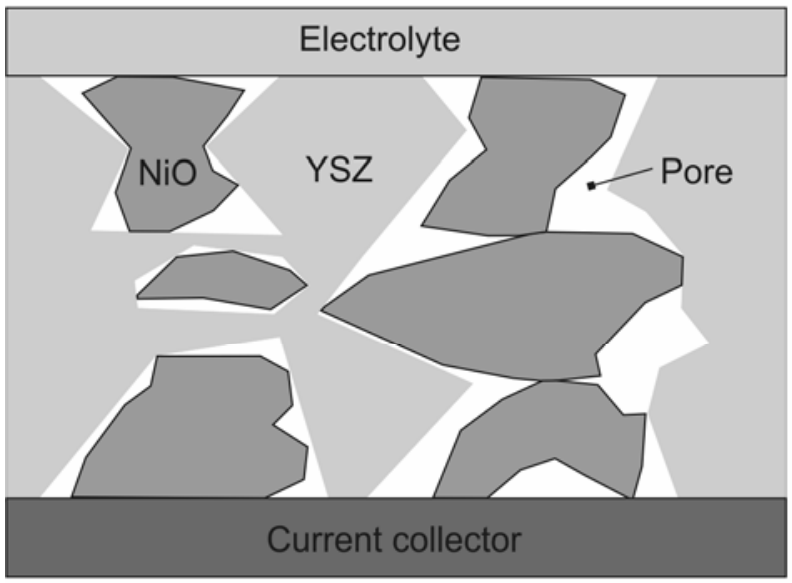

(c) First re-oxidized state (high temperatures)

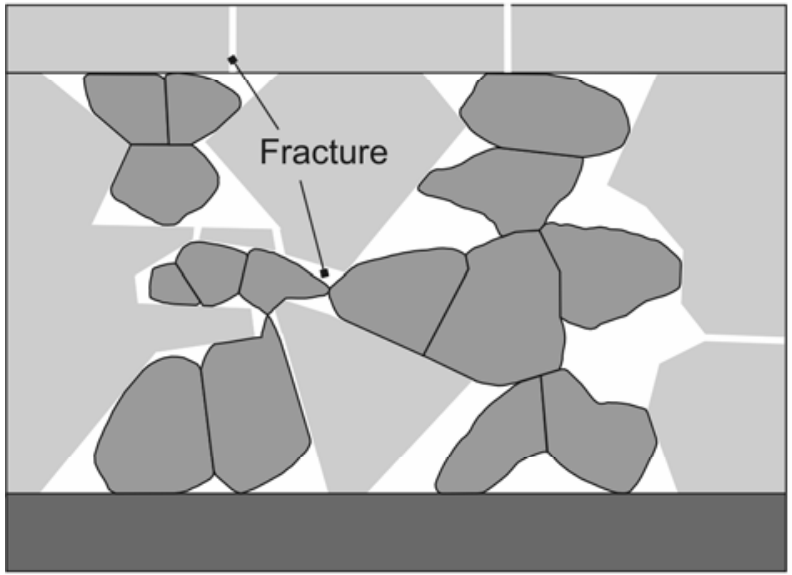

(e) N'th re-oxidized state (high temperatures)

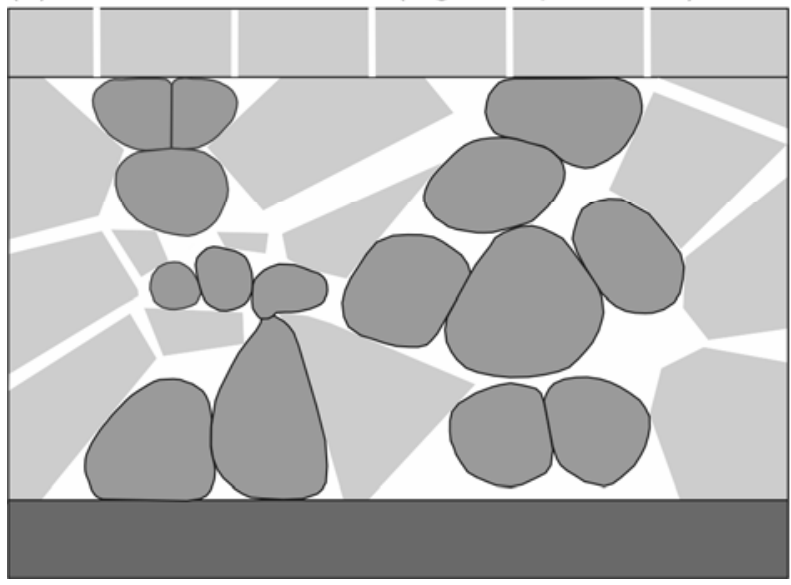

(b) First reduced state

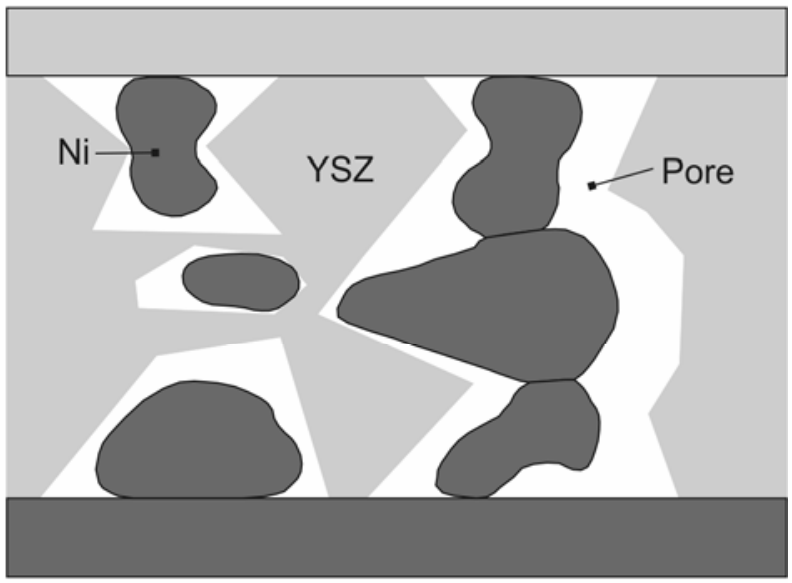

(d) Second reduced state

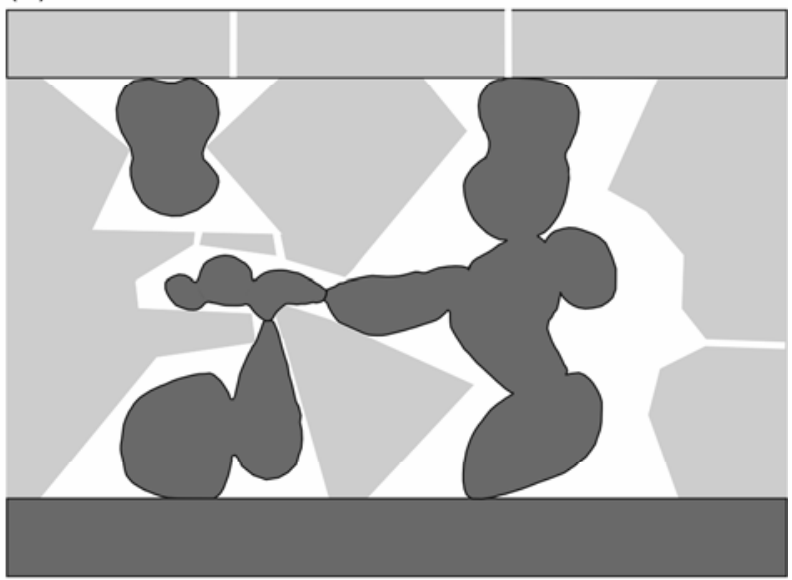

(f) N'th reduced state

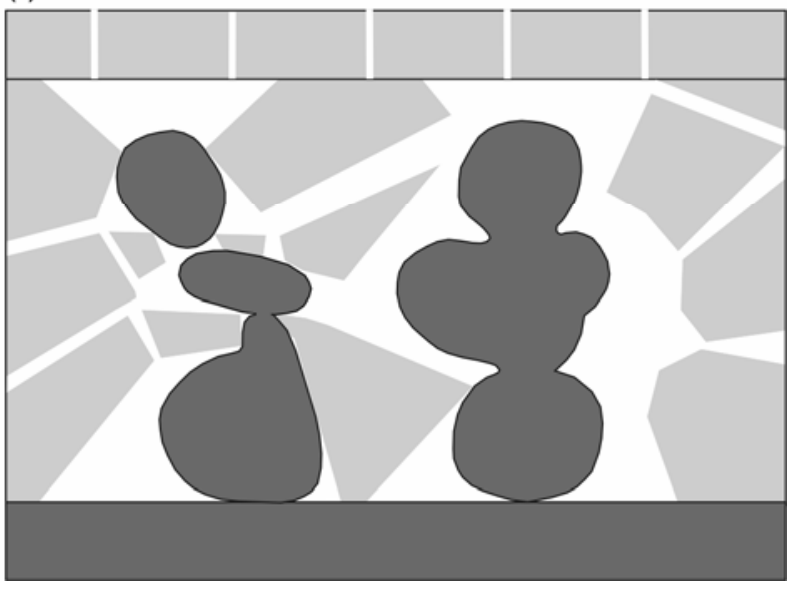

Figure 6: Cartoon illustrating the microstructural changes in the Ni/NiO-YSZ cermet upon successive redox steps. The darker gray particles represent respectively $\mathrm{NiO}$ and $\mathrm{Ni}$. The lighter gray matrix is the YSZ. The adjacent electrolyte and current collector are also shown. Pores and 
fractures are shown with white. (a) As-sintered state. (b) First reduced state. (c) First reoxidized state when oxidized at high temperature. (d) Second reduced state. (e) N'th re-oxidized state. (f) N'th reduced state.

\section{Conclusions}

The microstructural changes of nickel-YSZ cermets were characterized using DC conductivity measurements. Opposed to microscopy, the conductivity is a bulk average property. The conductivity was proven to be a sensitive measure of variations and changes in the Ni-YSZ microstructure, as for instance in the porosity.

A model of the processes occurring during redox cycling was proposed based on the electrical measurements. The model suggests that the dynamic reorganization of the $\mathrm{Ni} / \mathrm{NiO}$ phase when reduced and upon re-oxidation accounts for the redox instability of the anode. The oxide growth mode generates damage to the YSZ network, but will also promote improved percolation of the $\mathrm{Ni} / \mathrm{NiO}$-network until a critical porosity.

\section{Acknowledgement}

Dr. N. Bonanos (Risø National Laboratory) is acknowledged for help in designing and performing the measurements. Dr. K. V. Hansen (Risø National Laboratory) is acknowledged for providing the ICP-OES analyses. 


\section{References}

1. G. Robert, A. Kaiser, E. Batawi, Anode substrate design for RedOx-stable ASE cells, 6th European SOFC Forum proc. vol. 1, ed. M. Mogensen (European Fuel Cell Forum, Oberrohrdorf, Switzerland, 2004), 193-200.

2. D. Fouquet, A.C. Müller, A. Weber, E. Ivers-Tiffée, Kinetics of oxidation and reduction of Ni/YSZ cermets, Ionics, 9 (2003), 103-108.

3. G. Stathis, D. Simwonis, F. Tietz, A. Moropoulou, A. Naoumides, Oxidation and resulting mechanical properties of $\mathrm{Ni} / 8 \mathrm{Y} 2 \mathrm{O} 3$-stabilized zirconia anode substrate for solid-oxide fuel cells, J. Mater. Res., 17 (2002), 951-958.

4. T. Klemensoe, C. Chung, P.H. Larsen, M. Mogensen, The mechanism behind redox instability of anodes in high-temperature SOFCs, J. Electrochem. Soc., 152 (2005), A2186-A2192.

5. L. Kindermann, F.W. Poulsen, C. Bagger, In plane conductivity of improved Ni-cermet anodes, 3rd European SOFC Forum proc. vol. 2, ed. P. Stevens (European Fuel Cell Forum, Oberrohrdorf, Switzerland, 1998), 133-143.

6. D. Simwonis, F. Tietz, D. Stöver, Nickel coarsening in annealed Ni/8YSZ anode substrates for solid oxide fuel cells, Solid State Ionics, 132 (2000), 241-251.

7. R.J. Aaberg, R. Tunold, F.W. Poulsen, N. Bonanos, Short term structural changes in NiO/YSZ electrodes upon reduction, 2nd European SOFC Forum proc. vol. 1, ed. B. Thorstensen (European Fuel Cell Forum, Oberrohrdorf, Switzerland, 1996), 363-372.

8. M. Lang, T. Franco, M. Johnson, G. Schiller, P. Szabo, Characterisation of vacuum plasma sprayed planar solid oxide fuel cells during reduction-oxidation cycling, 6th 
European SOFC Forum proc. vol. 2, ed. M. Mogensen (European Fuel Cell Forum, Oberrohrdorf, Switzerland, 2004), 877-886.

9. G. Robert, A. Kaiser, K. Honegger, E. Batawi, Anode supported solid oxide fuel cells with a thick anode substrate, 5th European SOFC Forum proc. vol. 1, ed. J. Huijsmans (European Fuel Cell Forum, Oberrohrdorf, Switzerland, 2002), 116-122.

10. D.W. Dees, T.D. Claar, T.E. Easler, D.C. Fee, F.C. Mrazek, Conductivity of porous Ni/ZrO2-Y2O3 cermets, Electrochemical Storage, 134 (1987), 2141-2146.

11. W. Hu, H. Guan, X. Sun, S. Li, M. Fukumoto, I. Okane, Electrical and thermal conductivities of nickel-zirconia cermets, Journal of the Australian Ceramic Society, 81 (1998), 2209-2212.

12. A. Kuzjukevics, S. Linderoth, Interaction of $\mathrm{NiO}$ with yttria-stabilized zirconia, Solid State Ionics, 93 (1997), 255-261.

13. N.Q. Minh, T. Takahashi, Science and technology of ceramic fuel cells (Elsevier Science B.V., Amsterdam, 1995).

14. K.-R. Lee, S. H. Choi, J. Kim, H.-W. Lee, J.-H. Lee, Viable image analyzing method to characterize the microstructure and the properties of the Ni/YSZ cermet anode of SOFC, J. Power Sources, 140 (2005), 226-234.

15. S.P. Jiang, Sintering behaviour of $\mathrm{Ni} / \mathrm{Y} 2 \mathrm{O} 3-\mathrm{ZrO} 2$ cermet electrodes of solid oxide fuel cells, J. Mater. Sci., 38 (2003), 3775-3782.

16. D. Skarmoutsos, A. Tsoga, A. Naoumides, P. Nikolopoulos, 5 mol\% TiO2-doped NiYSZ anode cermets for solid oxide fuel cells, Solid State Ionics, 135 (2000), 439-444. 
17. S.P. Jiang, S.H. Chan, Development of Ni/Y2O3-ZrO2 cermet anodes for solid oxide fuel cells, Materials Science and Technology, 20 (2004), 1109-1118.

18. D. Skarmoutsos, P. Nikolopoulos, F. Tietz, I.C. Vinke, Physical characterization of Y0.25Zr0.60Ti0.15O2-x and its performance as a Ni/Y0.25Zr0.60Ti0.15O2-x anode cermet in an SOFC, Solid State Ionics, 170 (2004), 153-158.

19. A. Tsoga, P. Nikolopoulos, A. Kontogeorgakos, F. Tietz, A. Naoumides, Additives for improved long-term behaviour of the SOFC anode cermet, SOFC V proc. vol. 97-40, ed. U. Stimming, S. C. Singhal, H. Tagawa, W. Lehnert (The Electrochemical Society, Inc., Pennington, NJ, USA, 1997), 823-832.

20. W.Z. Zhu, S.C. Deevi, A review on the status of anode materials for solid oxide fuel cells, Materials Science and Engineering, A362 (2003), 228-239.

21. H. Itoh, Y. Hiei, T. Yamamoto, M. Mori, T. Watanabe, Optimized mixture ratio in YSZsupported Ni-YSZ anode material for SOFC, SOFC VII proc. vol. 2001-16, ed. H. Yokokawa, S.C. Singhal (The Electrochemical Society, Inc., Pennington, NJ, USA, 2001), 750-758.

22. T. Klemensø, C.C. Appel, M. Mogensen, In-situ observations of microstructural changes in solid oxide fuel cell anodes during redox cycling, Electrochemical and Solid-State Letters, 9 (2006), to be published.

23. D. Waldbillig, A. Wood, D.G. Ivey, Electrochemical and microstructural characterization of the redox tolerance of solid oxide fuel cell anodes, J. Power Sources, 145 (2005), 206215. 